\title{
A summer heat wave decreases the immunocompetence of the mesograzer, Idotea baltica
}

\section{Journal Article}

Author(s):

Roth, Olivia; Kurtz, Joachim; Reusch, Thorsten B. H.

Publication date:

2010

Permanent link:

https://doi.org/10.3929/ethz-b-000422873

Rights / license:

In Copyright - Non-Commercial Use Permitted

Originally published in:

Marine Biology 157(7), https://doi.org/10.1007/s00227-010-1433-5 


\title{
A summer heat wave decreases the immunocompetence of the mesograzer, Idotea baltica
}

\author{
Olivia Roth · Joachim Kurtz • Thorsten B. H. Reusch
}

Received: 5 December 2009 / Accepted: 22 March 2010 / Published online: 9 April 2010

(C) Springer-Verlag 2010

\begin{abstract}
Extreme events associated with global change will impose increasing stress on coastal organisms. How strong biological interactions such as the host-parasite arms-race are modulated by environmental change is largely unknown. The immune system of invertebrates, in particular phagocytosis and phenoloxidase activity response are key defence mechanisms against parasites, yet they may be sensitive to environmental perturbations. We here simulated an extreme event that mimicked the European heat wave in 2003 to investigate the effect of environmental change on the immunocompetence of the mesograzer Idotea baltica. Unlike earlier studies, our experiment aimed at simulation of the natural situation as closely as possible by using long acclimation, a slow increase in temperature and a natural community setting including the animals' providence with natural food sources (Zostera marina and Fucus vesiculosus). Our results demonstrate that a simulated heat wave results in decreased immunocompetence of the mesograzer Idotea
\end{abstract}

Communicated by H. O. Pörtner.

O. Roth $\cdot$ J. Kurtz $\cdot$ T. B. H. Reusch

Institute for Evolution and Biodiversity,

Westfälische Wilhelms-Universität Münster,

Hüfferstrasse 1, 48149 Münster, Germany

O. Roth

Institute for Integrative Biology,

Experimental Ecology, Universitätsstrasse 16,

ETH-Zentrum, 8092 Zürich, Switzerland

O. Roth $(\varangle) \cdot$ T. B. H. Reusch

Leibniz Institute for Marine Sciences, IFM-Geomar,

Evolutionary Ecology of Marine Fishes,

Düsternbrooker Weg 20, 24105 Kiel, Germany

e-mail: oroth@ifm-geomar.de baltica, in particular a drop of phagocytosis by $50 \%$. This suggests that global change has the potential to significantly affect host-parasite interactions.

\section{Introduction}

Global change may result in a changed pattern of coevolutionary hot and cold spots, as fluctuations of temperature can affect host and parasite genotypes into opposite directions (Gomulkiewicz et al. 2000). This is likely to disrupt species interactions and evolutionary equilibriums. Not only the mean temperature but also the variation in many abiotic parameters will increase, leading to rising frequencies of extreme climate events such as heat waves and storms (Frich et al. 2002). Whereas global average surface temperature is expected to increase by $1.8-4.0^{\circ} \mathrm{C}$ by the end of this century (IPCC 2007), regional increase is likely to even be higher, e.g. a rise of water temperature by $3-5^{\circ} \mathrm{C}$ in the Baltic Sea is predicted (Belkin 2009).

Parasites (here used in the evolutionary sense, including macroparasites, and microparasites like bacteria and viruses) reduce the fitness of their hosts and often impose strong selection pressures on them by continually evolving new ways to evade host defence. Hosts counteract with the evolution of efficient immune systems that rely on a high diversity of resistance alleles that recognize non-self and fight foreign parasites (Altizer et al. 2003; Boots and Bowers 2004).

Due to their shorter generation time, larger population size, and higher rate of reproduction, parasites and pathogens are thought to adapt to their hosts in a shorter time than hosts to their parasites (Kawecki and Ebert 2004). Environmentally induced changes such as global warming are thus likely to favour marine pathogens by shortening 
their generation time (Harvell et al. 2002). Short time studies suggest temperature to have an impact on virulence in various systems (Rosenberg and Ben-Haim 2002; Blanford et al. 2003; Thomas and Blanford 2003). An increased virulence may impose stronger selection pressure on the host immune defence.

Herbivores may be impacted by environmental change twofold. Either they are affected directly by increased temperature or $\mathrm{CO}_{2}$ and its associated metabolic stress, but in addition, they may suffer indirectly via altered food quality (e.g. (Veteli et al. 2002; Asshoff and Hättenschwiler 2005; Karowe 2007; Tylianakis et al. 2008). Changes in temperature, $\mathrm{pH}$ and salinity have been shown to impose stress onto marine freshwater invertebrates and to impact their immunity (Moullac and Haffner 2000; Mydlarz et al. 2006). Many terrestrial studies focused on plant-insect interactions under elevated temperature or " $\mathrm{CO}_{2}$ ", Here, plant composition and secondary substances are affected by global change, for example the secondary phenolic compounds have been shown to decrease (Veteli et al. 2002). If the same pattern exists for the marine realm, herbivores can be expected to feed on an altered food quality. This could result in a changed resource allocation trade-off where only limited resources for investment in different life-history traits may be available. As immunity is costly, trade-offs often occur between immunity and other life history traits (Sheldon and Verhulst 1996). An induced metabolic stress coupled with an altered food quality is thus likely to decrease immune response that leads to hosts highly susceptible to parasites and diseases.

Invertebrates rely exclusively on their innate immunity and lack a mechanistic homologue of the adaptive arm of the vertebrate immune system (Janeway and Medzhitov 2002), although some recent work suggests specificity upon secondary exposure to parasites and pathogens (Kurtz and Franz 2003; Sadd and Schmid-Hempel 2006; Roth and Kurtz 2009; Roth et al. 2009). The immune system of invertebrates can be divided into cellular and humoral defences. Phagocytosis represents the most important feature of cellular immunity (Jutras and Desjardins 2005). During phagocytosis, reactive oxygen species are produced with a high antimicrobial potential (Bachere et al. 1995). Important features of the humoral immune defence are the production of antimicrobial peptides and phenoloxidase activity, the production of melanin by the prophenoloxidase system (Hoffmann 2003).

Only few data on the impact of temperature changes on immune defence exist in marine invertebrates, mainly decapods (Steenbergen et al. 1978; Staples and Heales 1991; Chen et al. 1995, 2003; Dove et al. 2005; Robohm et al. 2005). While they represent important first steps, the conclusions about the natural impact of global change are limited. The increase of several degrees centigrade within few minutes used in previous studies is unrealistic for the marine realm where temperatures increase only slowly, but extreme values may persist for a longer time. We thus lack a good understanding of how immunocompetence may be comprised in a natural scenario of global change.

To investigate how future environmental change may affect immunocompetence, we calibrated the imposed experimental stress by in situ temperature measurements of the heat wave in Europe during the summer 2003 (Reusch et al. 2005). Marine invertebrates are likely to not only be affected by temperature but also by changes in their food source. To investigate both, direct effects by temperature and indirect effects by changing food conditions, we used a common algae/plant-grazer system of the Baltic Sea, the isopod Idotea baltica, the brown alga Fucus vesiculosus and the seagrass Zostera marina. Here, not only the animals had to cope with raising temperatures but also the algae and the seagrass. Hence, the interaction of the plant and the grazer is likely to be affected by global change. With this community approach, we tried to simulate a more natural situation to be able to investigate the effect of global change in the marine realm on the immunocompetence of a marine invertebrate.

\section{Materials and methods}

Study organism

Isopods of the genus Idotea are key herbivores within macrophyte meadows (seagrasses and macroalgae) throughout the northern hemisphere (Williams and Ruckelhaus 1993; Jaschinski and Sommer 2008). The study species I. baltica is abundant on macroalgal and seagrass beds in the Baltic Sea, especially on brown algae of the order Fucales and on the seagrass Zostera marina (Franke et al. 1999; Hemmi and Jormalainen 2002). Idotea prefers feeding on epiphytes, however, if absent, they feed directly on Fucus and Zostera (Jaschinski and Sommer 2008). I. baltica relies on permanent access to food, in its natural habitat it only rarely experiences phases of food deprivation, and is thus severely affected when food is temporarily limited (Gutow et al. 2007). Temporary starvation is known to result in delayed maturity and decreased reproduction (Gutow et al. 2007) as I. baltica have only limited storage of internal compounds such as lipids (Gutow et al. 2006).

\section{Animal collection and experimental design}

Idotea baltica were collected in a Zostera marina bed in Ebeltoft (Denmark, Baltic Sea) at the 6th of May 2008 while snorkelling. Sampling was done at ambient water temperature of $15^{\circ} \mathrm{C}$ in a water depth of $0.50-2.0 \mathrm{~m}$ at 
salinity of $14.5 \mathrm{psu}$. The animals were brought to our aquaria facilities in Münster and randomly distributed over six aquaria $(80 \times 40 \times 40 \mathrm{~cm}), 15$ animals per tank. The facility was provided with artificial seawater (Instant Ocean) with a salinity of 31.5 psu. This salinity is well within the range of salinities encountered by the experimental animals in the Kattegat area. With this high salinity, we could further minimize the risk of a Vibrio infection that would have potentially confounded the outcome of this experiment, as the risk of Vibrio infections is highest at increased temperatures and low salinity (Kaspar and Tampling 1993). During the whole experiment the animals had unlimited access to Zostera marina and Fucus vesiculosus planted in the aquaria.

Zostera marina shoots were collected in Doverodde (Denmark, North Sea) and Ebeltoft (Denmark, Baltic Sea) on the 5th of May and 6th of May while snorkelling. Fucus vesiculosus was collected in Ebeltoft on the 6th of May. Plants were transported to our aquaria facilities in Münster and replanted within $48 \mathrm{~h}$ into the aquaria.

Every aquarium housed two boxes filled to a height of $10 \mathrm{~cm}$ with sandy marine sediment from the Kiel Bight; each box was planted with a random mixture of 20 shoots randomly chosen from all locations and plants (Doverodde, Ebeltoft, seagrass, Fucus). Individuals of Fucus were placed with the attached stones at their holdfasts.

Within 1 week, the water temperature was slowly raised to Baltic summer conditions $\left(19^{\circ} \mathrm{C}\right)$, thereafter, plants and animals were given an acclimatization period of 23 days at $19^{\circ} \mathrm{C}$. Shoots were provided with natural light conditions and water was fertilized every 10 days (design after Bergmann, Winters, Reusch, unpublished).

The treatment consisted of a simulated heat wave, while control aquaria were kept at a constant temperature. On the 4 th of June the experiment started, and water temperature of half of the tanks was slowly increased from 19 to $26^{\circ} \mathrm{C}$ with temperature steps of $1^{\circ} \mathrm{C} /$ day. After reaching $26^{\circ} \mathrm{C}$, a constant temperature was kept for 1 week mimicking the 2003 European heat wave (Reusch et al. 2005). On the 15th of June, immunocompetence of the surviving Idotea baltica was measured. Due to high mortality (cannibalism) before the start of the temperature treatments, only eight Idotea per tank could be used for the experiment. During the experiment, no further mortality was observed. This indicates that survival was not influenced by the heat wave.

Immune measurements

\section{Hemolymph collection, injection of bacteria}

Immunocompetence of individual Idotea was quantified for animals from both the heat wave and control treatments. For measurements of immune defence, the animals were taken out of the aquaria into plastic vials with a water volume of $80 \mathrm{ml}$ filled with water from the tank they originated from. The vials were all carefully brought to the laboratory to minimize stress for the animals. Animals were punctured with a sterile needle. About $2 \mu \mathrm{l}$ of the outflowing hemolymph was collected into a $2-\mu 1$ microcapillary, flushed into a 0.2- $\mu$ l Eppendorf tube and immediately frozen in liquid nitrogen. Thereafter, $2 \mu \mathrm{l}$ of heat-killed Bacillus thuringiensis (concentration: $10^{8}$ cells $/ \mathrm{ml}$ ) dissolved in insect Ringer saline solution and labelled with FITC after standard protocols (Kurtz 2002) were injected into the animals using the same hole that was already punctured for taking hemolymph, to perform an in vivo phagocytosis assay. After injection of bacteria, the animals were immediately put back into the vials that were then placed into the aquaria facilities for $2 \mathrm{~h}$ (beforehand, lid was punctured with a needle to allow water exchange). Thereafter, $5 \mu \mathrm{l}$ of hemolymph was taken of every $I$. baltica into 5- $\mu$ l capillaries coated with PTU to prevent melanization (capillary was dipped into a saturated solution of phenylthiourea in methanol, and only used after evaporation). Hemocytes were rinsed into Lab-Tek Chamber slides filled with $250 \mu \mathrm{l}$ of Grace Insect medium and cooled on ice to proceed with the phagocytosis assay. All animals were thereafter killed and frozen at $-20^{\circ} \mathrm{C}$. Six animals had to be excluded as they died after the injection of bacteria independent of their experimental treatment.

\section{Phagocytosis and hemocyte count}

After addition of hemolymph, the Lab-Tek Chambers were kept for $15 \mathrm{~min}$ on ice and were thereafter placed into a wet chamber at room temperature for half an hour. During this time, hemocytes could attach to the slide. The phagocytosis assay was then performed as described by Roth and Kurtz (2009). Trypan blue was added to quench the fluorescent bacteria outside of the hemocytes (non-phagocytosed bacteria). After $15 \mathrm{~min}$, trypan blue was washed away with Grace insect medium until the slides were only slightly blue. DAPI was added to label hemocyte nuclei, most liquid and the upper part of the slide was taken away, glycerine gelatine was added and the slide was mounted with a cover slip.

During the next days, the phagocytic activity was quantified by counting the number of hemocytes. Hemocytes were differentiated as phagocytosing and non-phagocytosing hemocytes on an epifluorescent microscope at $400 \times$ magnification. Per well, five fields of view in a fixed order were quantified. As our measure of the phagocytic activity, the number of phagocytosing hemocytes was divided by the total number of hemocytes. This is used to indicate the percentage of hemocytes containing endocytosed bacteria (Steenbergen et al. 1978). 


\section{Phenoloxidase/hemocyanin activity}

Phenoloxidase activity measurements were performed after Irmak et al. (2005) with modifications. Into a $40 \mathrm{mM}$ HEPES buffer ( $N$-2-hydroxyethylpiperazine- $N$ '-2-ethanolsulfonic acid), $\mathrm{pH} 7.0$, a final concentration of $40 \mathrm{mM}$ dopamine was added as a substrate, and 0.06\% SDS (Sodium-dodecyl-sulphate) to induce phenoloxidase activity of hemocyanin (Jaenicke et al. 2009). $1 \mu \mathrm{l}$ of hemolymph was flushed into the substrate, and the change in absorption was thereafter immediately recorded at $490 \mathrm{~nm}$ on a Tecan Infinite 2 platereader for $2 \mathrm{~h}$, once every minute, at $30^{\circ} \mathrm{C}$. The maximal slope of the curve (Vmax) was calculated over 15 measurement points (15 min). Four animals had to be excluded due to measuring errors; they were randomly distributed over the treatments.

\section{Plant substrate content analysis}

To determine if the temperature increase affected immunocompetence of the isopods, or if the observed changes resulted from a combination of the increase in water temperature and changes in the composition of the substrate of the leaves and thalli, respectively, Idotea fed on, plant substrate content analyses were performed. In every aquarium seagrass from the two locations (Doverodde \& Ebeltoft) and Fucus vesicolusus were separately dried. Starch and sugar (glucose) were analysed with an enzymatic starch digestion and a spectrophotometric glucose test after invertase and isomerize addition (Hoch et al. 2002). Total $\mathrm{N}$ and $\mathrm{C}$ were measured using a $\mathrm{CHN}$ analyser (Model 900, LECO Instruments, St Joseph, MI, USA).

\section{Data analysis}

All data were tested for a significant Tank effect (random factor). Since this was not significant, the factor Tank was removed from the analyses and all tanks of the same treatment were pooled.

Hemocyte counts were Box-Cox transformed before analysis (hemocytes ${ }_{x}=\left(\right.$ hemocytes $\left.\left.^{0.2}-1\right) / 0.0116\right)$ to reach a normal distribution of the data. Phagocytic activity data were Box-Cox transformed prior to analysis to reach a normal distribution of the data $\left(\operatorname{phago}_{x}=\left(\operatorname{phago}^{0.2}-1\right) /\right.$ 1.1155). Vmax measurements of phenoloxidase activity fitted a normal distribution. ANOVAs were performed with treatment (heat wave vs. control) and sex (male vs. female) as fixed factors and with hemocyte counts, phagocytic activity or phenoloxidase activity as response variables.

The effect of the heat wave on non-structural carbohydrates (NSC values) was analysed in an ANOVA with Location/ Species (Seagrass/Doverodde, Seagrass/Ebeltoft, Fucus/
Ebeltoft) and Treatment (heat wave vs. control) as fixed factors. Before analysis, data were Box-Cox transformed to reach a normal distribution $\left(\mathrm{NSC}_{x}=\left(\mathrm{NSC}^{0.6}-1\right) / 0.4000\right)$. The effect of the heat wave on the $\mathrm{C} / \mathrm{N}$ ratio (carbon divided by nitrogen) was analysed in an ANOVA with Location/ Species and Treatment as fixed factors.

\section{Results}

Idotea baltica that experienced the stress event of a heat wave had a significantly decreased phagocytic activity compared to control animals (ANOVA: Treatment, $F_{1,38}: 2.74$, $P=0.0093$; Sex, $F_{1,38}: 0.68, P=0.4994$; Treatment $\times$ Sex, $F_{1,38}: 1.42, P=0.165$ ) (Fig. 1a). The number of hemocytes was not affected by a heat wave (ANOVA. Treatment, $F_{1,38}$ : $0.53, P=0.751$; Sex, $F_{1,38}: 0.72, P=0.475$; Treatment $\times$ Sex, $F_{1,38}: 0.85, P=0.403$ ) (Fig. $1 b$ ). Males had a significantly lower phenoloxidase activity than females, however, the heat wave did not affect phenoloxidase activity (ANOVA: Treatment, $F_{1,40}: 0.79, P=0.434$; Sex: $F_{1,40}$ : $2.45, P=0.019$; Treatment $\times \operatorname{Sex}, F_{1,40}: 0.90, P=0.373$ ) (Fig. 1c).

NSC (non-structural carbohydrates) differed between seagrass from the locations Doverodde and Ebeltoft, and also between seagrass and Fucus vesiculosus. A trend could be found towards an increased sugar and starch storage under heat stress (ANOVA, Location $F_{2,12}$ : 72.59, $P=0.0001$; Treatment $F_{1,12}: 2.65, P=0.09$; location $\times$ treatment $F_{2,12}: 1.53, P=0.26$ ) (Fig. 2).

The $\mathrm{C} / \mathrm{N}$ ratio was constant over the different locations and was not affected by a heat wave (ANOVA, Location $F_{2,12}$ : 0.76, $P=0.49$; Treatment $F_{1,12}: 0.01, P=0.99$; Location $\times$ Treatment $\left.F_{2,12}: 0.08, P=0.93\right)$.

\section{Discussion}

We here demonstrated that a realistic extreme event that mimicked the 2003-European heat wave (Schar and Jendritzky 2004) decreased phagocytic activity of the marine isopod Idotea baltica by about $50 \%$. Unlike earlier studies performed about effects of temperature change on immunocompetence, our set-up simulated a natural situation, by (1) increasing temperature slowly, reclined at a scenario of a heat wave in Northern Europe in summer 2003 and by (2) allowing animals to feed on their natural food sources, Fucus vesiculosus and Zostera marina that were planted directly into the tank. Given that phagocytosis is a major innate immune pathway in crustaceans, and that host-parasite interactions are among the strongest biological interactions in all ecosystems, such a decrease is of serious concern. 


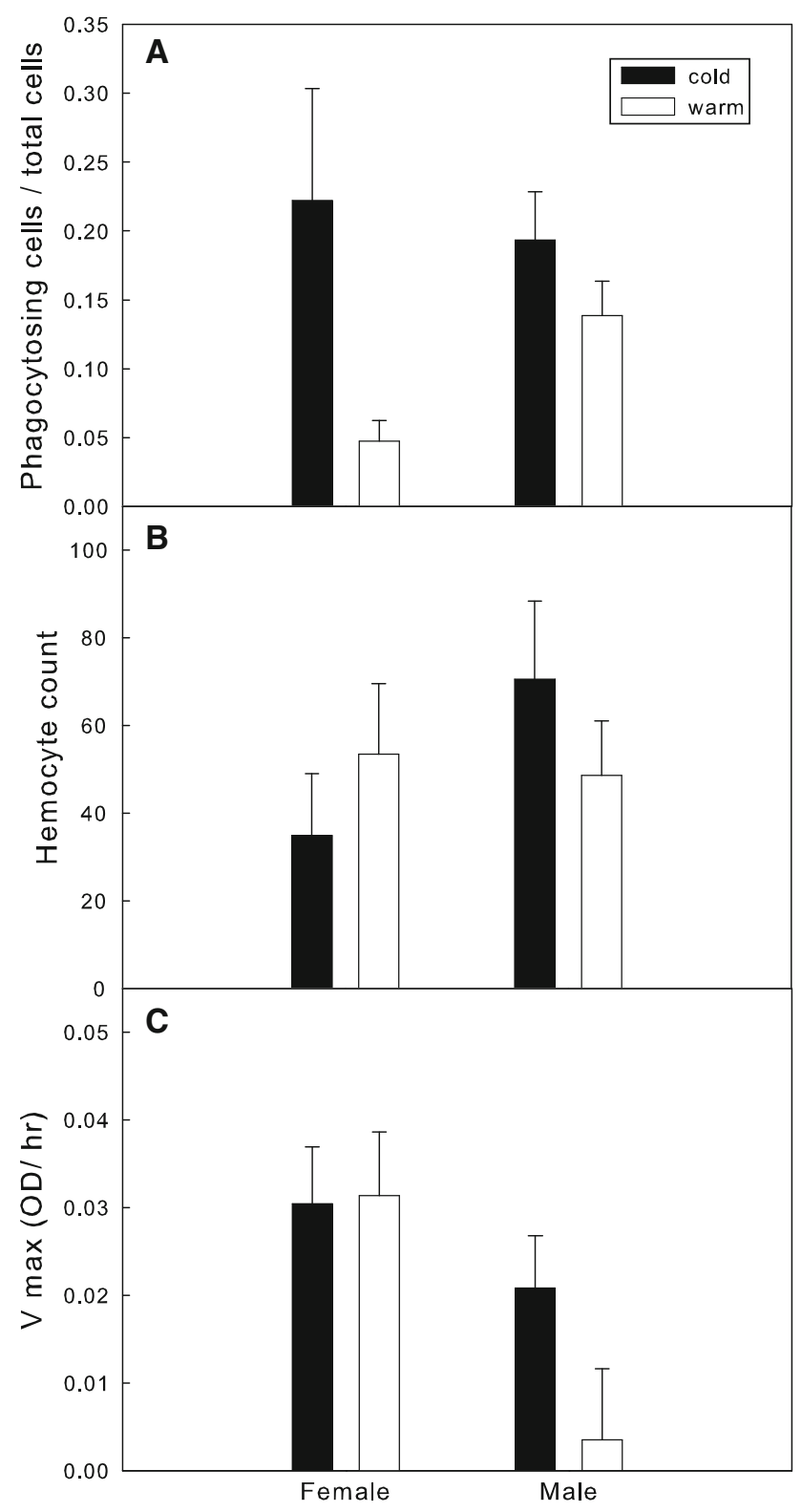

Fig. 1 Phagocytic activity (phagocytosing cells/total cells) (a) number of hemocytes (b) and phenoloxidase activity (c) of Idotea baltica that either went through a heat wave (warm: white bars) or were kept under control conditions (cold: black bar). Figure shows mean values + standard errors

In crustaceans, abrupt physico-chemical changes of seawater are known to affect metabolism, growth, moulting and survival (Staples and Heales 1991; Chen et al. 1995). Lobsters kept for 31 days at high temperatures $\left(23^{\circ} \mathrm{C}\right)$ had a decreased phagocytic activity compared to control lobsters at $16^{\circ} \mathrm{C}$ (Dove et al. 2005). Also in vitro temperature increase from $16^{\circ} \mathrm{C}$ to $24^{\circ} \mathrm{C}$ led to a drop of phagocytosis in lobsters (Homarus americanus) (Steenbergen et al. 1978). The giant freshwater prawn (Macrobrachium rosenbergii) increased its phagocytosis activity with intermediate temperature; however, at high temperatures $\left(35^{\circ} \mathrm{C}\right)$ it dropped

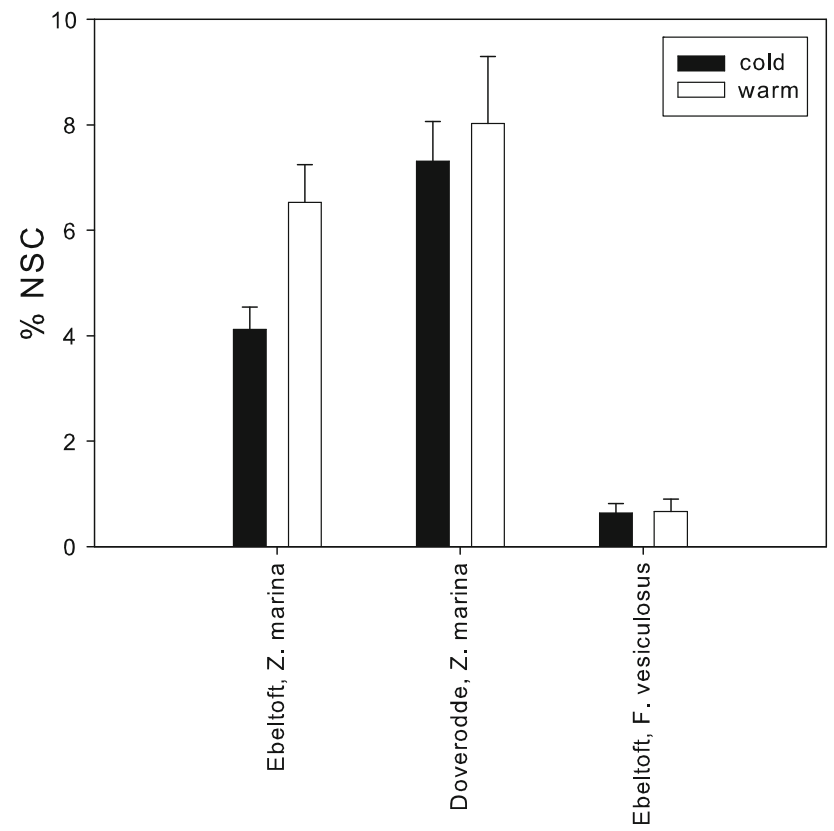

Fig. 2 Percentage of sugar and starch (combined in NSC) of leaves of either Zostera marina or Fucus vesiculosus collected in Ebeltoft and Doverodde exposed to a heat wave (warm: white bars) or exposed to control conditions (cold: black bars). Figure shows mean values + standard errors

(Cheng et al. 2003). Further, mortality of lobsters was increased at elevated temperatures after an infection with a pathogenic bacterium (Robohm et al. 2005). Even though the stress imposed onto the animals was lower in this study compared to earlier studies, we found a similar result.

Because temperature effects may also have changed the composition of leaves, respectively, thalli (increased sugar and starch storage, $P=0.09$ ), we cannot decide whether direct stress effects on the isopods metabolism, the alteration in food composition, or both are the underlying mechanisms.

If the alteration of carbohydrate composition was significant when using more replicates, this would have important ramifications for all plant-herbivore interactions in seagrass/macroalgal beds. The logical next experiment would be to decompose indirect food and direct metabolic stress effects on immunocompetence using a four-factorial experiment with I. baltica feeding on daily provided frozen food (like mosquito larvae or frozen seagrass) and I. baltica feeding on seagrass planted into their tank, both feeding treatment should be replicated and either go through the scenario of a heat wave or stay at control levels. Then, we could also investigate the alternative hypothesis, whether increased sugar and starch content may even increase immunocompetence and thus balance out the negative effects of immunosuppression via thermal stress. In addition, epiphyte growth on seagrass and macroalgae should be determined and NSC content should be measured, as 
epiphytes are the most preferred food source of Idotea and always present on seagrass. Further, laboratory bred isopods may be used to be able to exclude eventually confounding effects of age (potential senescence of immunity) or prior parasitic exposure.

Interestingly, male I. baltica have shown a lower humoral immunocompetence than females (phenoloxidase activity). In marine isopods, sexual dimorphism in immunity has as yet not been investigated. In many animal species, males have lower immunocompetence than females (Skarstein and Folstad 1996; Kurtz and Sauer 1999; Verhulst et al. 1999; Kurtz et al. 2000; Ryder and SivaJothy 2000). In invertebrates, one explanation for the sexual dimorphism in immunity may result from different life-history strategies of males and females. Whereas maximal female reproductive success is limited by the number of eggs a female can produce due to time constraints, maximal male reproductive success is limited by the accesses to mating partners. Females thus gain their fitness through increased longevity, while males gain fitness by increasing mating rates (Bateman's principle) (Bateman 1948; Clutton-Brock 1988). Since a stronger immune system may be needed for a longer life, Bateman's principle may account for sexual dimorphism in immunity (Rolff 2002).

During the acclimatization phase only, we observed substantial mortality among our experimental animals by cannibalism. Earlier studies working on marine isopods were faced with the same problem, as severe antagonistic interference in I. baltica is known to occur already at low densities, causing high mortality on juveniles and individuals which are about to moult (Franke and Janke 1998). Thus, laboratory populations reach their carrying capacity at a low density even though all necessary resources are still available in excess (Franke et al. 2007). Especially in feeding experiments, cannibalism may change the outcome of the study; however, in this study, cannibalism only occurred during the acclimatization phase, while no further cannibalism was observed during the experiment. To be able to perform experiments with larger replicate size and less confounding effects due to severe antagonistic interference, future studies should try to keep animals as single individuals in smaller tanks.

For the first time, we provide data about how over the short term (weeks), increasing temperature during a summer heat wave can compromise a major pathways of invertebrate immunity (in marine coastal systems). We here tried to simulate a natural situation by providing animals with their natural food source. The impact of global change on parasite resistance depends on multiple factors. The parasite pressure is likely to increase with global change due to a selection for higher virulence (Harvell et al. 2002). Even though the selection pressure on a strong host defence may counteractively be increased, the adaptation of the host to new environmental conditions is likely to take much longer than the adaptation of the parasite (Kawecki and Ebert 2004). This time delay coupled with the here presented negative short-term effect of a heat wave on the immunocompetence of the host, is likely to lead to hosts with higher susceptibilities to parasites and diseases. In a natural situation, global change could thus drastically affect the arms race between hosts and parasites and have a disruptive negative impact on species interactions and the persistence of key species such as herbivores.

Acknowledgments We want to thank Günter Hoch from the University of Basel for analysing leaf content. Without the "Aquatron-team" that provided the facility and the technical support this experiment would have not been accomplished, many thanks to Peter Nelle, Birgit Fricke, Nina Bergmann and Gidon Winters. We are grateful for the help of Roman Asshoff during the experiment. We thank Gisep Rauch for comments on an earlier version of this manuscript. This study was supported by a grant from the Swiss National Science Foundation (3100A0-112992 to J.K.). O.R. was supported by the Volkswagen Stiftung.

\section{References}

Altizer S, Harvell D, Friedle E (2003) Rapid evolutionary dynamics and disease threats to biodiversity. Trends Ecol Evol 18:589-596

Asshoff R, Hättenschwiler S (2005) Growth and reproduction of the alpine grasshoper Miramella alpina feeding on $\mathrm{CO} 2$ enriched dwarf shrubs at treeline. Oecologia 142:191-201

Bachere E, Miahle E, Rodriguez J (1995) Identification of defence effectors in the haemolymph of crustaceans with particular reference to the shrimp Penaeus japonicus (Bate): prospects and application. Fish Shellfish Immun 5:137-143

Bateman AJ (1948) Intra-sexual selection in Drosophila. Heredity 2:349-368

Belkin IM (2009) Rapid warming of large marine ecosystems. Prog Oceanogr 81:207-213

Blanford S, Thomas MT, Pugh C, Pell JK (2003) Temperature checks the Red Queen? Resistance and virulence in a fluctuating environment. Ecol Lett 6:2-5

Boots M, Bowers RG (2004) The evolution of resistance through costly acquired immunity. Proc R Soc Lond Ser B 271:715-723

Chen JC, Lin MN, Ting YY, Lin JN (1995) Survival, haemolymph osmolarity and tissue water of Penaeus chinensis juveniles acclimated to different salinities and temperature levels. Comp Biochem Physiol 110:253-258

Cheng W, Chen S-M, Want F-I, Hsu P-I, Liu C-H, Chen J-C (2003) Effects of temperature, $\mathrm{pH}$, salinity and ammonia on the phagocytic activity and clearance efficiency of giant freshwater prawn Macrobrachium rosenbergii to Lactococcus garvieae. Aquaculture 219:111-121

Clutton-Brock TH (1988) Reproductive success. University of Chicago Press, Chicago

Dove ADM, Allam B, Powers JJ, Sokolowski MS (2005) A prolonged thermal stress experiment on the American lobster, Homarus americanus. J Shellfish Res 24:761-765

Franke H-D, Janke M (1998) Mechanisms and consequences of intraand interspecific interference competition in Idotea baltica (Pallas) and Idotea emarginata (Fabricius) (Crustacea: Isopoda): a laboratory study of possible proximate causes of habitat segregation. J Exp Mar Biol Ecol 227:1-21 
Franke H-D, Gutow L, Janke M (1999) The recent arrival of the oceanic isopod Idotea metalica Box off Helgoland (German Bight, North Sea): an indication of a warming trend in the North Sea? Helgolander Meeresun 52:347-357

Franke H-D, Gutow L, Janke M (2007) Flexible habitat selection and interactive habitat segregation in the marine congeners Idotea baltica and Idotea emarginata (Crustacea, Isopoda). Mar Biol 150:929-939

Frich P, Alexander LV, Della-Marta P, Gleason B, Haylock M, Tank A, Peterson T (2002) Observed coherent changes in climatic extremes during the second half of the twentieth century. Climate Res 19:193-212

Gomulkiewicz R, Thompson JN, Holt RD, Nuismer SL, Hochberg ME (2000) Hot spots, cold spots, and the geographic mosaic theory of coevolution. Am Nat 156:156-174

Gutow L, Strahl J, Wiencke C, Franke H-D, Saborowski R (2006) Behavioural and metabolic adaptations of marine isopods to the rafting life style. Mar Biol 149:821-828

Gutow L, Leidenberger S, Boos K, Franke H-D (2007) Differential life history response of two Idotea species (Crustacea: Isopoda) to food limitation. Mar Ecol Prog Ser 344:159-172

Harvell CD, Mitchell CE, Ward JR, Altizer S, Dobson AP, Ostfeld RS, Samuel MD (2002) Climate warming and disease risks for terrestrial and marine biota. Science 296:2158-2162

Hemmi A, Jormalainen V (2002) Nutrient enhancement increases performance of a marine herbivore via quality of its food algae. Ecology 83:1052-1064

Hoch G, Popp M, Körner C (2002) Altitudinal increase of mobile carbon pools in Pinus cembra suggests sink limitation of growth at the Swiss treeline. Oikos 98:361-374

Hoffmann JA (2003) The immune response of Drosophila. Nature 426:33-38

IPCC (2007) Climate change 2007: synthesis report: summary for policymakers

Irmak P, Kurtz J, Zimmer M (2005) Immune response in Porcellio scaber (Isopoda: Oniscidea) copper revisited. Eur J Soil Biol 41:77-83

Jaenicke E, Fraune S, May S, Irmak P, Augustin R, Meesters C, Decker $\mathrm{H}$, Zimmer M (2009) Is activated hemocyanin instead of phenoloxidase involved in immune response in woodlice? Dev Comp Immunol 33:1055-1063

Janeway CA, Medzhitov R (2002) Innate immune recognition. Ann Rev Immunol 20:197-216

Jaschinski S, Sommer U (2008) Functional diversity of mesograzers in an eelgrass-epiphyte system. Mar Biol 154:475-482

Jutras I, Desjardins M (2005) Phagocytosis: at the crossroads of innate and adaptive immunity. Annu Rev Cell Dev Biol 21:511-527

Karowe DN (2007) Are legume-feeding herbivores buffered against direct effects of elevated carbon dioxide on host plants? A test with the sulfur butterfly, Colias philodice. Glob Change Biol 13:2045-2051

Kaspar CW, Tampling ML (1993) Effects of temperature and salinity on the survival of Vibrio vunificus in seawater and shellfish. Appl Environ Microbiol 59:2425-2429

Kawecki TJ, Ebert D (2004) Conceptual issues in local adaptation. Ecol Lett 7:1225-1241

Kurtz J (2002) Phagocytosis by invertebrate hemocytes: causes of individual variation in Panorpa vulgaris scorpionflies. Microsc Res Tech 57:465-468

Kurtz J, Franz K (2003) Evidence for memory in invertebrate immunity. Nature 425:37-38

Kurtz J, Sauer K (1999) The immunocompetence handicap hypothesis: testing the genetic predictions. Proc R Soc Lond Ser B 266:25152522
Kurtz J, Wiesner A, Gotz P, Sauer KP (2000) Gender differences and individual variation in the immune system of the scorpionfly Panorpa vulgaris (Insecta : Mecoptera). Dev Comp Immunol 24:1-12

Moullac G, Haffner P (2000) Environmental factors affecting immune responses in Crustacea. Aquaculture 191:121-131

Mydlarz LD, Jones LE, Havell CD (2006) Innate immunity, environmental drivers and disease ecology of marine and freshwater invertebrates. Annu Rev Ecol Evol Syst 37:251-288

Reusch TBH, Eherls A, Hammerli A, Worm B (2005) Ecosystem recovery after climatic extremes enhanced by genotypic diversity. Proc Natl Acad Sci USA 102:2826-2831

Robohm RA, Draxler AFJ, Wieczorek D, Kapareiko D, Pitchford S (2005) Effects of environmental stressors on disease susceptibility in American lobsters: a controlled laboratory study. J Shellfish Res 24:773-779

Rolff J (2002) Bateman's principle and immunity. Proc R Soc Lond Ser B 269:867-872

Rosenberg E, Ben-Haim Y (2002) Microbial diseases of corals and global warming. Environ Microbiol 4:318-326

Roth O, Kurtz J (2009) Phagocytosis mediates specificity in the immune defence of an invertebrate, the woodlouse Porcellio scaber (Crustacea: Isopoda). Dev Comp Immunol 33:11151-11155

Roth O, Sadd BM, Schmid-Hempel P, Kurtz J (2009) Strain-specific priming of resistance in the red flour beetle, Tribolium castaneum. Proc R Soc Lond Ser B 276:145-151

Ryder J, Siva-Jothy MT (2000) Male calling song provides a reliable signal of immune function in a cricket. Proc R Soc Lond Ser B 263:1171-1175

Sadd BM, Schmid-Hempel P (2006) Insect immunity shows specificity in protection upon secondary pathogen exposure. Curr Biol 16:1206-1210

Schar C, Jendritzky G (2004) Climate change: hot news from summer 2004. Nature 432:559-560

Sheldon BC, Verhulst S (1996) Ecological immunology: costly parasite defences and trade-offs in evolutionary ecology. Trends Ecol Evol 11:317-321

Skarstein F, Folstad I (1996) Sexual dichromatism and the immunocompetence handicap: an observational approach using Arctic charr. Oikos 76:359-367

Staples DJ, Heales DS (1991) Temperature and salinity optima for growth and survival of juvenile banana prawns Penaeus merguiensis. Aquaculture 14:23-30

Steenbergen JF, Steenbergen SM, Schapiro HC (1978) Effects of temperature on phagocytosis in Homarus americanus. Aquaculture 14:23-30

Thomas MB, Blanford S (2003) Thermal bioloy in insect-parasite interactions. Trends Ecol Evol 18:344-350

Tylianakis JM, Didham RK, Bascompte J, Wardle DA (2008) Global change and species interactions in terrestrial ecosystems. Ecol Lett 11:1351-1363

Verhulst S, Dieleman S, Parmentier H (1999) A tradeoff between immunocompetence and sexual ornamentation in domestic fowl. Proc Natl Acad Sci USA 96:4478-4481

Veteli TO, Kuokkanen K, Julkunen-Tiitto R, Roininen H, Tahvanainen J (2002) Effects of elevated CO2 and temperature on plant growth and herbivore defensive chemistry. Glob Change Biol 8:1240 1252

Williams SL, Ruckelhaus MH (1993) Effects of nitrogen availability and herbivory on eelgrass (Zostera marina) and epiphytes. Ecology 74:904-918 